\title{
Micropropagation through Nodal Culture of an Economically Important Forest Tree Species Gmelina Arborea Roxb
}

\author{
M. Rambabu' ${ }^{1}$ D. Ujjwala ${ }^{2}$, M. Rajinikanth ${ }^{3}$, N. Rama Swamy ${ }^{4}$ \\ ${ }^{1}$ Department of Botany, Govt. Degree College, Mahabubabad, Warangal (Dist.) -506101, Telangana, India \\ ${ }^{2}$ Department of Botany, RMS-Nereda-Kuravi, Warangal (Dist)-506104, Telangana, India \\ ${ }^{3,4}$ Department of Boitechnology, Kakatiya University, Warangal (Dist.) -506009, Telangana, India
}

\begin{abstract}
Micropropagation technique plays a vital role in tree improvement program. The species Gmelina arborea (Verbanaceae) is an economically and medicinally important forest tree. In the present investigation, the nodal explants containing single node were cultured on MS medium containing $30 \mathrm{~g} / \mathrm{L}$ sucrose supplemented with $0.2-5.0 \mathrm{mg} / \mathrm{L}$ BAP/Kn and also without plant growth regulators. Maximum percentage of response and high frequency number of multiple shoots formation was observed at $0.6 \mathrm{mg} / \mathrm{L}$ BAP compare with Kn in the specie G.arborea.
\end{abstract}

Keywords: micropropagation, in vitro, Gmelina arborea, auxins, cytokinins, BAP, Kn.

\section{Introduction}

Micropropagation through proliferation of axillary buds is a common technique in in vitro multiplication of forest trees. Axillary bud proliferation approach typically results in many fold increase in shoot number. Each culture passage makes feasible to obtain as many as possible propagules from a single explant and they are true-to-type. The induction of axillary bud proliferation seems to be applicable as a means of micropropagation in many woody forest trees. Proliferation of these axillary buds from tree species may be difficult due to contamination, phenolic exudation and tissue maturity (Bonga, 1982a, b). Rapid clonal propagation has gained considerable importance as a promising tool for multiplication of woody plants. So there are few reports of timber trees of Combretaceae successfully established by tissue culture technology (Joshi et al., 1991). Commercially important forest tree species have been multiplied by using this technique. They are: Eucalyptus (Lakshmisita, 1979; Grewal et al., 1980, Gupta et al., 1981); Melia azaderach (Raghuraman and Ramanujam, 1998); Celastrus paniculatus (Arya et al., 2002); Maytenus emerginata (Rathore et al., 1992); Zizyphus mauritiana (Sudershan et al., 2000); Balanites aegyptica, Citrus lemon, Syzygium cuminii (Rathore et al., 2004a, b); Swietenia mahagoni (Nagarajan et al., 2006).

Gmelina arborea, Roxb. (Vern: Tel. Gummadi Teaku) belongs to Verbanaceae is a large to medium sized, fast grown, deciduous tree up to $40 \mathrm{~m}$ tall and $140 \mathrm{~cm}$ in diameter. The wood is yellow-grayish or reddish-white with soft and light. It is one of the best timber for making furniture, constructions, plywood, black doors, general carpentry and packages. It is also used in carriages, carvings, musical instruments and ornamental work etc. (Alam et al., 1988).The total plant parts of G.arborea were used as a very good medicine. Roots of this species are one of the constituents of "Dashamula", is well known Ayurvedic formulation. Roots and bark are useful in treatment of hallucinations, fever, dyspepsia, stomachagalgia and burning
sensation(Tiwari, 1995; Hartwell, 1967-1971; Shirwaiker et.al., 2003). Leaf Juice is used for ulcers. Flowers and fruits are used for treating leprosy, anemia, constipation, and also known to inhibit platelet aggregation. The leaves are harvested for fodder for animals and silkworms (Sharma et.al., 2001; Duke, 1984; Faiza and Dharakhshanda, 1996, 1998; Little, 1983).

\section{Materials Methods}

Young and healthy nonwoody branches from two years old plants of G.arborea were used as explants. Shoots were excised free of leaves, trimmed into $(3 \mathrm{~cm})$ segments containing a single node. These explants were washed for 30 minutes under running tap water. Then treated with 5\% (w/v) Teepol for 5 minutes, followed by rinsing in distilled water for five times. Surface sterilization was carried out with $0.1 \%(\mathrm{w} / \mathrm{v}) \mathrm{HgCl}_{2}$ for 5 minutes followed by five rinses in sterile distilled water. These sterilized explants were dried on sterile tissue paper. The nodal segments were trimmed into 1.0-2.0 cm long having one node and were used as explants.

The sterilized nodal segments containing single node were inoculated on MS medium containing $30 \mathrm{~g} / \mathrm{L}$ sucrose without growth regulators (MSO) and also supplemented with different concentrations (0.2-5.0 $\mathrm{mg} / \mathrm{L})$ of BAP/Kn.

After inoculation, all the cultures were incubated under cool white-fluorescent lights at an intensity of 40-60 $\mu \mathrm{mol} \mathrm{m} \mathrm{s}^{-1}$ for 16 hrs photoperiod at $25 \pm 2^{0} \mathrm{C}$.

\section{Results}

The initial response exhibited by the nodal explants was an enlargement and subsequent breaking of the axillary bud. The time taken for bud breaking was found to be varied depending on the concentrations and combinations of growth regulators used. New shoots were developed after 


\section{International Journal of Science and Research (IJSR) \\ ISSN (Online): 2319-7064 \\ Index Copernicus Value (2013): 6.14 | Impact Factor (2015): 6.391}

two weeks of culture and attained height of $2 \mathrm{~cm}$ after 3 weeks. Maximum percentage of response (90\%) was recorded at $0.6 \mathrm{mg} / \mathrm{L}$ BAP followed by $0.8 \mathrm{mg} / \mathrm{L}($ Table- 1$)$. Average number of shoots per explant was also recorded at the same(Fig.1). As the concentration of BAP increased, lowest percentage of response was observed.Nodal segments cultured on MS medium fortified with different concentrations of $\mathrm{Kn}$, showed varied results. Maximum percentage (80\%) of response was observed at $0.6 \mathrm{mg} / \mathrm{L} \mathrm{Kn}$. Lowest percentage of response was recorded at high concentrations of $\mathrm{Kn}$.

\section{Discussion}

Axillary bud proliferation and elongation was observed in all the concentrations and combinations of growth regulators used except on MS basal medium in G.arborea. Early bud breakage and shoot emergence was observed at $0.6 \mathrm{mg} / \mathrm{L}$ $\mathrm{BAP} / \mathrm{Kn}$. Maximum percentage of response and high frequency number of multiple shoots formation were found at the same concentration of BAP. It was also showed superiority in inducing more number of multiple shoots in comparison to Kn. Similarly Purohit and Kukda (2004) have reported the multiple shoots formation from nodal explants of forest tree Wrightia tinctoria on MS medium with 2.0 $\mathrm{mg} / \mathrm{L}$ BAP.

Anitha and Pullaiah (2002) found that BAP was the best cytokinin in enhancing the shoot buds proliferation in Sterculia foetida than to Kn and TDZ. Sunnichan et al., (1998) have recorded the highest frequency number of shoots from axillary bud on MS + $6.62 \mu \mathrm{m}$ BAP than to Kn in Sterculia urens. At higher concentration of BAP and Kn reduced markedly the number of shoots as found in the present investigation. These finding are similar to our present observations that BAP showed superiority over Kn.. Superiority of BAP was reported in many other woody tree species too (Joshi et al., 1991; Gupta et al., 1993; Purohit and Dave, 1996; Sunnichan et al., 1998). Whereas Tiwari et al., (2004) have reported the multiple shoots induction from nodal culture on $\mathrm{MS} / \mathrm{B}_{5}$ medium supplemented with 0.2 $\mathrm{mg} / \mathrm{L}$ IBA in an endangered forest tree Pterocarpus marsupium. Sunnichan et al., (1998) have reported the multiple shoots induction on $\mathrm{BAP} / \mathrm{Kn}$ in gum-karaya (Sterculea urens) and Jagdish Chandra et al., (1999) in Pisonia alba as found in G.arborea. But Appa Rao (2004) had observed the synergistic effect of both cytokinins BAP and $\mathrm{Kn}$ combination by enhancing the shoot buds proliferation in Sapindus trifoliatus. Similarly Kathiravan and Ignacimuthu (1999) found the efficiency of both the cytokinins $\mathrm{BAP}$ and $\mathrm{Kn}$ together in the medium in Canavalia virosa.

The size of the nodal explant was also found to play an important role in initiation, proliferation and elongation of the shoots. Sharon and D'souza (2000) and D'souza and Sharon (2001) and Rama Swamy et al., (2004) have reported that the smaller explants could initiate more multiples than that of longer nodal explants. Similar findings were also noted in Sapindus trifoliatus (Appa Rao, 2004). Nodal segment orientation at the time of culture also influences on the proliferation of shoots. Vertical orientation of Wrightia tinctoria explants was found better than horizontal orientation in terms of number of proliferated shoots (Purohit et. al., 2004) as observed in G.arborea.

\section{Future Scope}

The species Gmelina arborea is a very good economic and medicinal important forest tree. This protocol for in vitro nodal culture has been established in G.arborea which plays a vital role in rapid multiplication of the species

\section{Acknowledgement}

The corresponding author would like thanks to University Grants Commission for providing financial assistance

Table 1: Effect of BAP/Kn on in vitro nodal culture in G.arborea

\begin{tabular}{|c|c|c|c|}
\hline $\begin{array}{c}\text { Concentration } \\
\text { of PGR } \\
(\mathrm{mg} / \mathrm{L})\end{array}$ & $\begin{array}{l}\% \text { of } \\
\text { response }\end{array}$ & $\begin{array}{l}\text { Average No. of } \\
\text { shoots/explant } \pm \\
\quad(\mathrm{SE})^{\mathrm{a}}\end{array}$ & $\begin{array}{c}\text { Mean length of } \\
\text { shoot }(\mathrm{cm}) \pm(\mathrm{SE})^{\mathrm{a}}\end{array}$ \\
\hline MSO & $\mathrm{b}$ & $\mathrm{b}$ & $\mathrm{b}$ \\
\hline \multicolumn{4}{|c|}{ BAP } \\
\hline 0.2 & 75 & $2.5 \pm 0.5$ & $5.0 \pm 0.15$ \\
\hline 0.4 & 80 & $3.5+0.10$ & $6.0 \pm 0.5$ \\
\hline 0.6 & 90 & $5.0 \pm 0.01$ & $6.5 \pm 0.5$ \\
\hline 0.8 & 84 & $3.5 \pm 0.05$ & $6.0 \pm 0.13$ \\
\hline 1 & 72 & $3.0 \pm 0.20$ & $5.5+0.10$ \\
\hline 2 & 70 & $2.5 \pm 0.02$ & $5.0 \pm 0.12$ \\
\hline 3 & 65 & $1.5 \pm 0.13^{*}$ & $4.0 \pm 0.01$ \\
\hline 4 & 60 & $1.0 \pm 0.15^{*}$ & $3.5 \pm 0.20$ \\
\hline 5 & 52 & $1.0 \pm 0.13^{*}$ & $3.0 \pm 0.10$ \\
\hline \multicolumn{4}{|c|}{$\underline{\underline{K n}}$} \\
\hline 0.2 & 65 & $2.0 \pm 0.10$ & $3.5 \pm 0.10$ \\
\hline 0.4 & 75 & $3.0 \pm 0.5$ & $4.0 \pm 0.12$ \\
\hline 0.6 & 80 & $3.5 \pm 0.15$ & $5.0 \pm 0.50$ \\
\hline 0.8 & 70 & $2.5 \pm 0.10$ & $4.5 \pm 0.12$ \\
\hline 1 & 65 & $2.0 \pm 0.13$ & $4.0 \pm 0.01$ \\
\hline 2 & 60 & $2.0 \pm 0.01$ & $3.0 \pm 0.05$ \\
\hline 3 & 50 & $1.0 \pm 0.15^{*}$ & $2.0 \pm 0.20$ \\
\hline 4 & 40 & $1.0 \pm 0.10^{*}$ & $1.5 \pm 0.15$ \\
\hline 5 & 40 & $1.0 \pm 0.02^{*}$ & $1.0 \pm 0.13$ \\
\hline
\end{tabular}

${ }^{\mathrm{a}} \mathrm{SE}=$ Standard Error; * $=$ With callus induction; $\mathrm{b}=\mathrm{no}$ response 


\section{International Journal of Science and Research (IJSR) \\ ISSN (Online): 2319-7064}

Index Copernicus Value (2013): 6.14 | Impact Factor (2015): 6.391

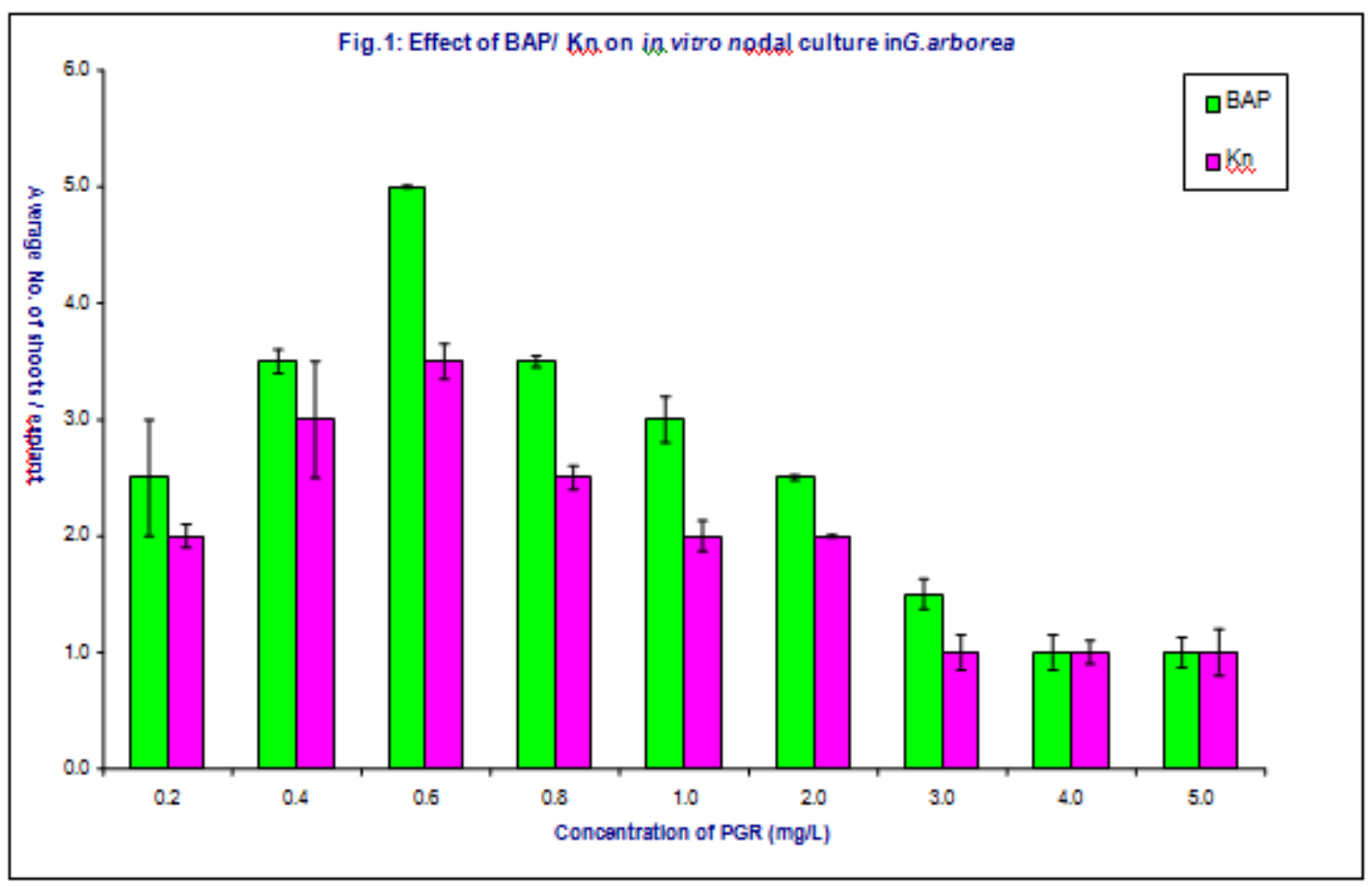

Figure 2
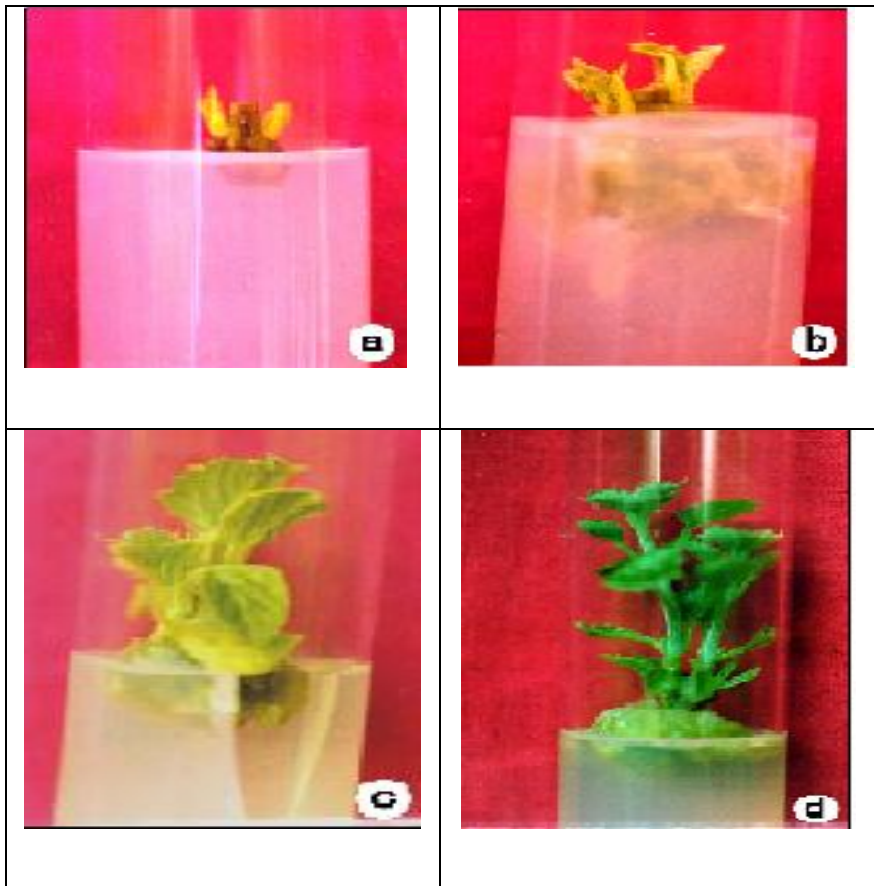

Figure 2: Nodal explants were cultured o MS medium supplemented with $0.6 \mathrm{mg} / \mathrm{L} \mathrm{BAP}$

a) single node containing two axillary buds cultured on the medium

b) sprouting of axillary buds after two weeks of culture

c) multiple shoots formation after four weeks of culture

d) elongation of multiple shoots after two months of culture

\section{References}

[1] Alam, MK., Siddiqui, N.A. and Das, D. (1988). Fodder free of Bangladesh forest research institute, Chittagang, Bangladesh, 167 p.
[2] Anitha, S. and Pullaih, T. (2002). Shoot regeneration from hypocotyls and shoot tip explants of Sterculia foetida L. derived seedlings. Taiwania, 47 : 62-69.

[3] Appa Rao, K. (2004). In vitro micropropagation of Sapindus trifoliatus L. M.Phil. Thesis, submitted to Kakatiya University, Warangal.

[4] Arya, V., Singh, R.P. and Shekhawat, N.S. (2002). A micropropagation protocol for mass multiplication and off-site conservation of Celastrus paniculatus - A vulnerable medicinal plant of India. J. Sustainable Forestry, 14 : 107-120.

[5] Bonga, J.M. (1982a). Vegetative propagation in relation to juvenility, maturity and rejuvenation. In :Tisue Culture in Forestry, (eds.) Bonga, J.M. and Durzan, D.J., Martinus Nijhoff Publications, The Hague, pp.387412.

[6] Bonga, J.M. (1982b). Tissue Culture of economically important plants,(ed.) Rao, A.N. Costed publication, Singapore, pp.191-196.

[7] Das, T.D. and Mitra, G.C. (1990). Micropropagation of Eucalyptus tereticornis Smith. Plant Cell Tiss. \& Org. Cult., 22 : 95-103.

[8] Duke,J.A. in ed. An herb a day Ayurvedic Typescript.;(1984).

[9] D’Souza, M.C. and Sharon, M. (2001). In vitro clonal propagation of Annatto (Bixa orellana L.). In vitro Cell Dev. Biol. Plant., 37 : 168-172.

[10] Faiza,H.and Darakhshanda,S. The inhibition of platelet aggregation and related physiological responses with crude drug extract of Gmelina arborea, in:Sixth International Symposium on New trends in Natural Products Chemistry,Publication.pp.229286;(1996,1998).

[11] Jagadish Chandra, K.S., Rachappaji, S., Gowda, K.R.D. and Tharasaraswathi, K.J. (1999). In vitro propagation of Pisonia alba (L.) Spanogar (Lettence tree)-A threatened species. Phytomorphology, 49:43-47. 


\section{International Journal of Science and Research (IJSR) \\ ISSN (Online): 2319-7064 \\ Index Copernicus Value (2013): 6.14 | Impact Factor (2015): 6.391}

[12] Joshi, M.S., Shekhawat, N.S. and Rathore, T.S. (1991). Micropropagation of Anogeissus pendula Edgew and arid forest tree. Indian J. Expt. Biol. 29:615-618.

[13] Lakshmi Sita, G. and Vaidyanathan, C.S. (1979). Rapid multiplication of Eucalyptus by multiple shoot production. Curr. Sci., 48:350-351.

[14] Little,E.L. Jr. Common fuelwood crops: a handbook for their identification McClain printing Co.,Persons.Wv.(1983).

[15] Grewal, S., Ahuja, A. and Atal, C.K. (1980). In vitro proliferation of shoot apices of Eucalyptus citroidera Hock. Indian J. Exp., Biol., 18:775-777.

[16] Gupta, P.K., Nadgir, A.L., Mascarenhas, A.F. and Jagannathan, V. (1980). Tissue culture of forest trees. Clonal multiplication of Tectona grandis (teak) by tissue culture. Plant Sci. Lett., 17:259-268.

[17] Gupta, P.K., Mascarenhas, A.F. and Hagannathan, V. (1981). Tissue culture of forest trees-clonal propagation of mature trees of Eucalyptus citrioidora Hook, by tissue culture. Plant Sci., Lett., 20:195-201.

[18] Gupta, P.K., Pullman, G., Timmis, R., Kreitinger, M., Carison, W.C., Grob, J. and Welty, E. (1993). Forestry in the $21^{\text {st }}$ century - The Biotechnology of somatic embryogenesis. Biotechnology, 11:454-459

[19] Hartwell. J.L. Plants used against cancer. A survey Lloydia 30-34;(1967-1971).

[20] Kathiravan, K. and Ignacimuthu, I. (1999). Micropropagation of Canavalia virosa (Roxb.) Wight \& Arn. A medicinal plant. Phytomorphology, 49:61-66.

[21] Kukda, G. (1994). Clonal propagation of toy wood tree Wrightia tinctoria through tissue culture and biotechnology, Ph.D. Thesis, Mohanlal Sukhadia University, India.

[22] Nagarajan, S.M., Rajashekharan, S., Kandasamy, S. and Jaychandra, R. (2006). In vitro studies on Swietenia mahagoni (L.) Jacq. Asian J. Microbiol. Biotech. Environ. Sci., 8: 473-474.

[23] Purohit, S.D. and Kukda, G. (2004). Micropropagation of an adult tree - Wrightia tinctoria. Indian J. Biotech., 3:216-220. Purohit, S.D. and Kukda, G. (2004). Micropropagation of an adult tree - Wrightia tinctoria. Indian J. Biotech., 3:216-220.

[24] Purohit, S.D. and Dave, A. (1996). Micropropagation of Sterculia urens Roxb. an endangered tree species. Plant Cell Rep., 15:704-706.

[25] Raghuraman, G. and Ramanujam, M.P. (1998). Micropropagation of Melia azaderach (L.). J. Swamy Bot. Cl., 15:1-5.

[26] Rama Swamy, N., Ugandhar, T., Praveen, M., Venkataiah, P., Rambabu, M., Upender, M. and Subhash, K. (2005). Somatic embryogenesis and plantlet regeneration from cotyledon and leaf explants of Solanum surattense. Indian J. Biotechnol. 4: 414418.

[27] Rathore, T.S., Singh, R.P. and Shekhawat, N.S. (1991). Clonal propagation of desert teak (Tecomella undulata) through tissue culture. Plant Science, 79:217-222.

[28] Rathore, T.S., Deora, N.S. and Shekhawat, N.S. (1992). Cloning of Maytenus emerginata (wild) Ding Hou - a tree of the Indian Desert, through tissue culture. Plant Cell Rep., 11:449-451.

[29] Rathore, J.S., Vinod Rathore, Shekhawat, N.S., Singh, R.P., Liler, G., Mahendra Phulwaria and Dagla, H.R. (2004a). Micropropagation of woody plants. In : Plant Molecular Biology and Molecular Markers (eds.) Srivastava, P.S., Alka Narula and Sheela Srivastava, Anamaya Publishers, New Delhi, pp.195-205.

[30] Rathore, J.S., Shekhawat, N.S., Singh, R.P., Rathore, J.S. and Dagla, H.R. (2004b). Cloning of adult trees of Jamun (Syzygium cumini). Indian J. Biotech., 3:241245.

[31] Sharon, M. and D'Souza, M. (2000). In vitro clonal propagation of annatto (Bixa orellana L.). Curr. Sci., 7: 1532-1535.

[32] Sharma,P.C.,Yelne,M.B. and Dennis, T.J. Database on medicinal plants used in Ayurveda,Vol.3,Central Council for Research in Ayurveda and Siddha, Department of ISM and Ministry of health and family welfare. Government of India, pp. 217-228;(2001).

[33] Shirwaiker., A.. Ghosh., S. and Rao, P.G.M. Effect of Gmelina arborea Roxb. Leaves on wound healing in rats, J.Nat. Remedies 3/1:45-48; (2003).

[34] Shekhawat, N.S., Rathore, T.S., Singh, R.P., Deora, N. and Rao, S.R. (1993). Factors affecting in vitro clonal propagation of Prosopis cineraria. Plant Growth Reg., 12:273-280.

[35] Sudershan, C., Aboel, M.N. and Hussain, J. (2000). In vitro propagation of Zizyphus mauritiana cultivar umrdn by shoot tip and nodal multiplication. Curr. Sci., 80:290-292.

[36] Sunnichan, V.G., Shivanna, K.R. and Mohan Ram, H.Y. (1998). Micropropagation of gum karaya (Sterculia urens) by adventitious shoot formation and somatic embryogenesis. Plant Cell Rep., 17:951-956.

[37] Hartwell. J.L. Plants used against cancer. A survey Lloydia 30-34;(1967-1971).

[38] Tiwari, S.K., Kashyap, M.K., Ujjaini, M.M. and Agarwal, A.P. (2002). In vitro propagation of Lagerstromia parviflora Roxb. from adult tree. Indian J. Expt. Biol., 40: 212-215.

[39] Tiwari, S., Shah, P. and Singh, K. (2004). In vitro propagation of Pterocarpus marsupium Roxb. an endangered medicinal tree. Indian J. Biotech., 3: 323464. 